\title{
Ultimate and Elemental Analysis of Some Common Charcoal in Southwestern Nigeria
}

\author{
Jacob Ademola Sonibare, Michael Abidemi Oke*, Onakpohor Anthony, \\ Akeredolu Funsho Akeredolu
}

Environmental Engineering Research Laboratory, Department of Chemical Engineering, Obafemi Awolowo University, Ile-Ife, Nigeria

Email address:

asonibar@yahoo.com (J. A. Sonibare), okemicheal@gmail.com (M. A. Oke)

${ }^{*}$ Corresponding author

\section{To cite this article:}

Jacob Ademola Sonibare, Michael Abidemi Oke, Onakpohor Anthony, Akeredolu Funsho Akeredolu. Ultimate and Elemental Analysis of Some Common Charcoal in Southwestern Nigeria. Modern Chemistry. Vol. 9, No. 1, 2021, pp. 13-24. doi: 10.11648/j.mc.20210901.13

Received: March 10, 2021; Accepted: March 29, 2021; Published: April 16, 2021

\begin{abstract}
Common charcoals from different wood species were collected, identified and prepared for analysis. Ultimate and elemental analyses were carried out. In this study, identified charcoal were characterized. The result showed that in the ultimate analysis, Carbon, Hydrogen and Oxygen are the major content of the charcoal samples and are of great importance for the heating value. Sulphur and Nitrogen content were resent in low in quantity. XRF was used in the elemental analysis and the following elements were detected ( $\mathrm{Na}, \mathrm{Cr}, \mathrm{Ni}, \mathrm{Cd}, \mathrm{Al}, \mathrm{K}, \mathrm{Mn}, \mathrm{P}, \mathrm{Ca}, \mathrm{Si}, \mathrm{Mg}, \mathrm{Ti}, \mathrm{Fe}$ ) In the charcoal samples, the percentages of $\mathrm{Si}$ and $\mathrm{Al}$ are high while the percentages of $(\mathrm{Cd}, \mathrm{Fe}, \mathrm{Na}, \mathrm{Ti}, \mathrm{Ni}, \mathrm{Mg}, \mathrm{P}, \mathrm{K}, \mathrm{Cr})$ were low. Percentage of silicon was between $50 \%$ to $65 \%$ in Albizia zygia, Milicia excelsa, Terminalia avicennioides, Funtumia elastica, Milletia thonningii and Hevea brsiliensis with Hevea brasiliensis having the highest which suggested high slagging propensity. Anogeissus leiocarpa, Afzelia bipindensis, Vitellia paradoxum, and Burkea africana have high $\mathrm{Na} / \mathrm{K}$. The ratio of $\mathrm{Ca} / \mathrm{Mg}$ is greater than 2 in all the samples. LOI ranges from 54.56 $-7.88 \%$ with a mean of $25.978 \pm 22.909 \%$.
\end{abstract}

Keywords: Charcoal, Analysis, Concentration, Ultimate, Elemental

\section{Introduction}

The use of fossil fuels has led to serious greenhouse gas emissions and environmental hazards. It is necessary to replace fossil fuels with alternative energy that meet energy demands. As a result of this, because it is a cheap, diversified and abundant resource biomass is of greater importance. Biomass energy can be further advanced, with sustainable development of new biomass resources and improvement of technologies for effective conversion of them [1]. Elements that are present in charcoal include carbon, nitrogen, hydrogen, oxygen, sulphur and other elements. This elements are either beneficial or harmful or both to the ecosystem. Charcoal is a solid biomass.

$\mathrm{X}$-ray fluorescence (XRF) spectroscopy is one of the major well-grounded tools for the determination of the elemental composition of rocks, sediments and earth material samples ([2, $3,4,5])$. For several years, it has been used for the determination of geochemical composition of several trace and important elements at a very high levels (ppm). This has also find its application in the successful investigation of samples from geological, archaeological and industrial site [5]. The principle used by XRF shows that every atom give off a wavelength feature or a relative abundance of X-ray photons of energy that can be calculated [4]. This method has been used in the investigation of Earth materials from a range of settings and environments ([6-11]).

Lignocellulosic materials contains metals such as $\mathrm{Mg}, \mathrm{Ca}, \mathrm{Na}$, and $\mathrm{K}$ that are essential for plant growth. The composition of metals in charcoal may be increased by environmental growth with heavy metal contamination. Studies have shown that the presence of metal species, such as $\mathrm{Mg}, \mathrm{Ca}, \mathrm{Na}$, and $\mathrm{K}$, could greatly affect the character of lignocellulosic materials during pyrolysis $([12,13])$

Inorganic elements, like $\mathrm{Fe}, \mathrm{K}, \mathrm{Na}, \mathrm{Si}, \mathrm{Mg}, \mathrm{Al}$, and $\mathrm{Ca}$, are widely present in biomass and they can significantly affect the pyrolysis techniques and products distribution [14]. The 
essence of using biomass as a source of energy is closely linked with the problem of high environmental hazard as a result of their disposal. This cannot be excluded because biomass comprises of other elements aside $\mathrm{C}, \mathrm{H}$, and $\mathrm{O}$ that may be naturally hazardous [15]. In the process of biomass pyrolysis, these other elements are evenly distributed in the product like $\mathrm{Cl}, \mathrm{S}, \mathrm{P}$ and alkaline earth metals [16] and may (a) leads to critical damage to human health and the ecosystem; (b) cause serious operational problems like deposition, agglomeration, heated side corrosion and slagging; and (c) serve as catalyst in the pyrolysis process. ([17, 18]). Some heavy metal are also present in the biomass which can be harmful to human health and the environment at large such as $\mathrm{Cd}, \mathrm{Ni}, \mathrm{Cr}$, As, Pb, etc. This study analyses the elements present in the charcoal samples and gives an overview of the influence and impact of these elements.

\section{Materials and Methods}

Ten charcoal samples were collected in southwestern Nigeria. The samples were identified and prepared for analysis. The charcoal species includes: Anogeissus leiocarpa (Ayin), Afzelia bipindensis (Ayan), Vitellaria paradoxum (Emi), Burkea Africana (Asapa), Albizia zygia (Ayunre), Hevea brasiliensis (Rubber), Milicia excelsa (Iroko), Terminalia avicennioides (Idi), Funtumia elastica (Ire), Milletia thonningii (Ito).

\subsection{Study Area}

The study area is south-western Nigeria and these includes of Lagos, Ogun, Oyo, Osun, Ondo and Ekiti states. It is also called the south west geographical zone of Nigeria and the map is shown in figure 1. The longitude of the area lies $2^{\circ} 31^{1}$ and $6^{\circ} 00^{1}$ East and Latitude $6^{\circ} 21^{1}$ and $8^{\circ} 37^{1} \mathrm{~N}$ [19] with about $77,818 \mathrm{~km}^{2}$ land area and the population is about 32.5 million in 2006 [20]. South western, Nigeria is bounded in the North by Kogi and Kwara states, in the South by the Gulf of Guinea, in the East by Delta and Edo states and in the West by Benin Republic. The study area had a forest cover of 842,499 ha and 85 constituted forest reserves.

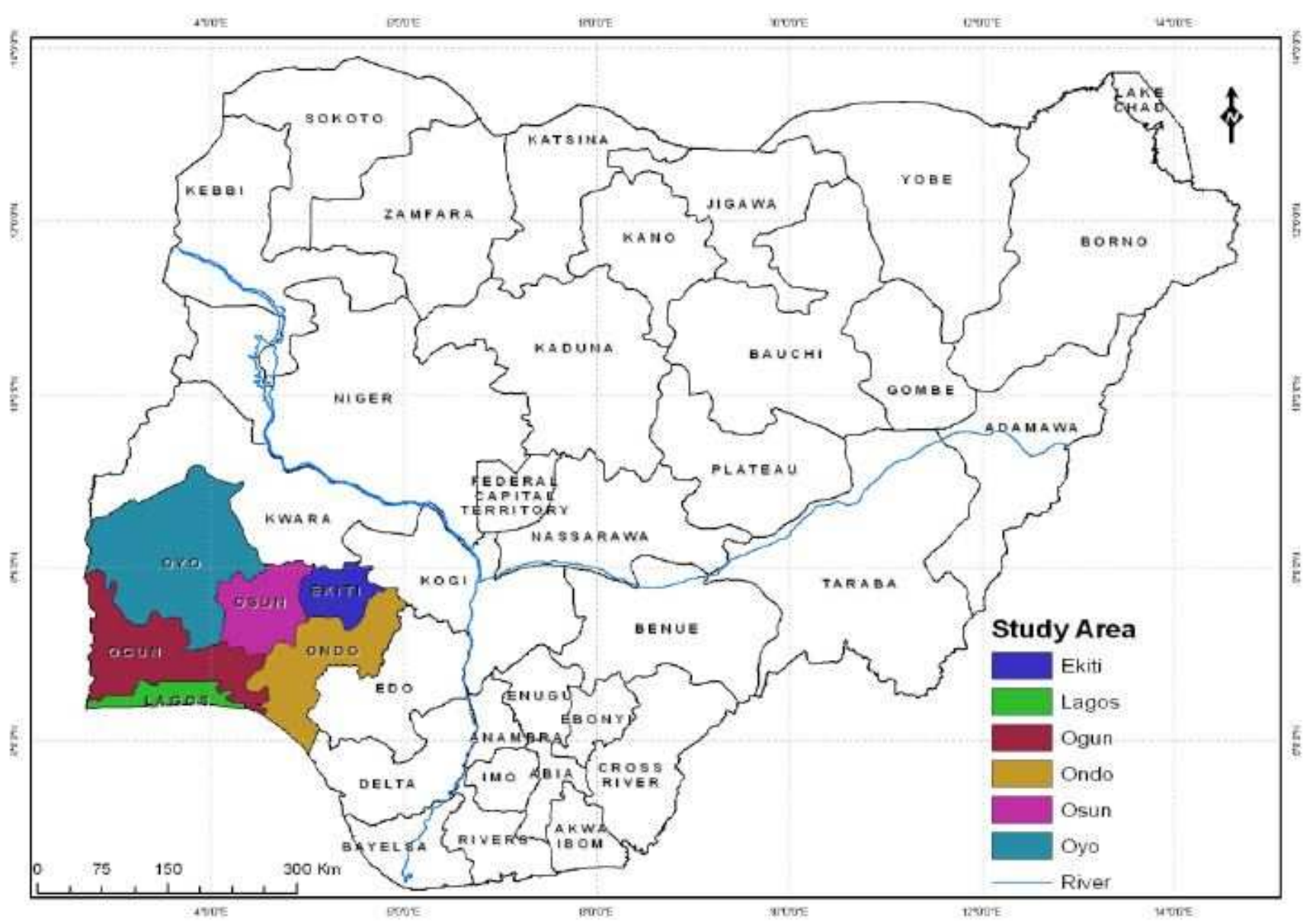

Figure 1. Map showing the study area [21].

\subsection{Ultimate Analysis}

This analysis basically involves the determination of the percentage of $\mathrm{C}$ (Carbon), $\mathrm{H}$ (Hydrogen), $\mathrm{O}$ (Oxygen), $\mathrm{N}$ (Nitrogen), S (Sulphur).

\subsubsection{Determination of Carbon and Hydrogen}

A solid of a known mass is subjected to burning in dry oxygen so as to convert the hydrogen and carbon to water $\left(\mathrm{H}_{2} \mathrm{O}\right)$ and carbon (IV) oxide $\left(\mathrm{CO}_{2}\right)$ respectively. After burning, the 
combustion products are passed over weighed tubes of anhydrous calcium chloride $\left(\mathrm{CaCl}_{2}\right)$ and potassium hydroxide $(\mathrm{KOH})$ which absorb $\mathrm{H}_{2} \mathrm{O}$ and $\mathrm{CO}_{2}$ respectively. The weight of water formed is represented by the increase in weight of $\mathrm{CaCl}_{2}$ tube while the weight of carbon dioxide produced is represented by the increase in the weight of $\mathrm{KOH}$ in the tube. Percentage of Hydrogen $(\mathrm{H})$ and Carbon $(\mathrm{C})$ in the sample was estimated.

$\mathrm{A}$ is the weight of sample taken.

$\mathrm{B}$ is the increase in the weight of $\mathrm{CaCl}_{2}$ tube.

$\mathrm{C}$ is the increase in the weight of $\mathrm{KOH}$ tube.

$$
\begin{array}{r}
\% \text { of carbon in the sample }=\frac{12 C}{44 A} \times 100 \\
\% \text { of hydrogen in the sample }=\frac{2 \mathrm{~B}}{18 \mathrm{~A}} \times 100
\end{array}
$$

\subsubsection{Determination of Nitrogen}

Kjeldahal's method was used in the determination of nitrogen in the specimen. $1.00 \mathrm{~g}$ of the prepared solid waste specimen was weighed and recorded as $\mathrm{w}_{8}(\mathrm{~g})$. The specimen was heated with concentrated tetraoxosulphate (VI) acid $\left(\mathrm{H}_{2} \mathrm{SO}_{4}\right)$ in the presence of Potassium tetraoxosulphate (VI) salt $\left(\mathrm{K}_{2} \mathrm{SO}_{4}\right)$ and Copper (II) tetraoxosulphate (VI) salt $\left(\mathrm{CuSO}_{4}\right)$ in a long necked flask called Kjeldahal's flask so as to convert the nitrogen in the specimen into ammonium sulphate $\left(\mathrm{NH}_{4}\right)_{2} \mathrm{SO}_{4}$. The formation of a clear solution showed that all the nitrogen has been convert to ammonium sulphate $\left(\mathrm{NH}_{4}\right)_{2} \mathrm{SO}_{4}, 50 \%$ of Sodium hydroxide $(\mathrm{NaOH})$ was used for treating the resulting solution.

The ammonia formed was distilled over and absorbed in a certain amount of standard $\mathrm{H}_{2} \mathrm{SO}_{4}$ solution. Titration against standard solution of $\mathrm{NaOH}$ was used to determine the volume of un-used acid. The quantity of acid neutralized by released $\mathrm{NH}_{3}$ from the specimen was then evaluated.

(Titre Value) $\mathrm{V}_{\mathrm{t}}=\mathrm{V}_{1}-\mathrm{V}_{2}\left(\mathrm{~cm}^{3}\right)$

Where $\mathrm{V}_{1}=$ volume of $\mathrm{H}_{2} \mathrm{SO}_{4}$ neutralized $\left(\mathrm{cm}^{3}\right)$

$\mathrm{V}_{2}=$ volume of $\mathrm{H}_{2} \mathrm{SO}_{4}$ neutralized in determination $\left(\mathrm{cm}^{3}\right)$

$\mathrm{W}_{\mathrm{g}}=$ weight of the specimen $(\mathrm{g})$

$$
\text { Nitrogen in the specimen }=\frac{0.0014 \times 5 \times V t}{W g} * 100
$$

\subsubsection{Determination of Sulphur}

A specimen of $25 \mathrm{ml}$ were weighed, dissolved and pipetted into $50 \mathrm{ml}$ standard flasks observed through $20 \mathrm{ml}$ gelatine $\mathrm{BaCl}_{2}$ solution and scaled up to $50 \mathrm{ml}$ mark. The solutions were permitted to stay for 0.5 hour. The Spectrophotometer was used to study the absorbance of the standard solution at $420 \mathrm{~nm}$. The specimen concentration was estimated by plotting the graphs of absorbance against concentration of standards. Percentage of sulphur in the specimen was evaluated using the following equation. The average value for each specimen was calculated when the processes were repeated twice.

$\%$ of Sulphur in the Specimen $=\frac{\mathrm{R} \times \mathrm{V} \times \mathrm{Df}}{\text { weight of sample used }}$

\section{$\mathrm{Df}=$ Dilution factor}

\subsubsection{Determination of\% of Hydrogen and Oxygen in the Sample}

The addition of the $\%$ of sulphur, total carbon and nitrogen subtracted from 100 will give the $\%$ of oxygen and hydrogen in the specimen.

$$
\% \mathrm{H}+\% \mathrm{O}=100-(\% \text { of } \mathrm{C}+\mathrm{N}+\mathrm{S})
$$

Determination of Elemental Composition

Samples were prepared at the Environmental Laboratory of the Department of Chemical Engineering, Obafemi Awolowo University Ile-Ife, Osun state. The samples were dried and the dried samples were pulverized into a fine powder with an agate mortar and pestle. During preparation cover both faces of the compression die to avoid contamination and the mixture of samples. Each pulverized ground sample (powder pellet) was then weighed to be about $5 \mathrm{~g}$ prior to analysis. These samples were analyzed with a Shimadzu EDX-720HS which allows the quantitative analysis of the elements and gives high X-ray intensity. To perform the loss of ignition (LOI) test, a crucible of dried sample $1.0 \mathrm{~g}$ was placed in a furnace and ignited at $900^{\circ} \mathrm{C}$ for $30 \mathrm{~min}$ to obtain a constant mass. The LOI was estimated using the formula below:

$$
\text { LOI }=\frac{M_{0}-M_{1}}{M_{0}} \times 100
$$

\section{Results and Discussion}

The result of ultimate analysis which includes carbon content, hydrogen content, oxygen content, sulphur content and nitrogen content are shown on figure 2 - figure 6 .

The result shows the variation of different element in the charcoal samples. The content of carbon is higher than any other element. It expected that high carbon content should increase the calorific value. The carbon content ranges from $76.50 \%$ for Afzelia bipindensis (Ayan) to $86.05 \%$ for Hevea brasilensis (Rubber). The hydrogen content varies from $5.24 \%$ for Milicia excelsa (Iroko) to $10.40 \%$ for Burkea africana (Asapa). The oxygen content ranges from $2.67 \%$ for Afzelia bipindensis (Ayin) to $17.11 \%$ for Burkea africana (Asapa). Biomass compared to fossil fuels with relatively low sulfur content in the wood 0.02 to 0.05 wt.\% [22]. Sulphur in the burning process is converted to sulfur oxides which are pollutant to the environment and also be irritating to the human respiratory system. ([23, 24, 25]). The Sulphur content ranges from $0.00 \%$ for Burkea africana (Asapa), Funtumia elastica (Ire) and Milletia thonningii (Ito) to $1.03 \%$ for Hevea brasilensis (Rubber). The nitrogen content varies from $0.15 \%$ for Burkea africana (Asapa) to $0.71 \%$ for Afzelia bipindensis (Ayan). The percentage of each content were presented in figure 2 - figure 6 .

Where: $\mathrm{R}=$ Reading from the graph

$\mathrm{V}=25 \mathrm{ml}$ (total volume) 


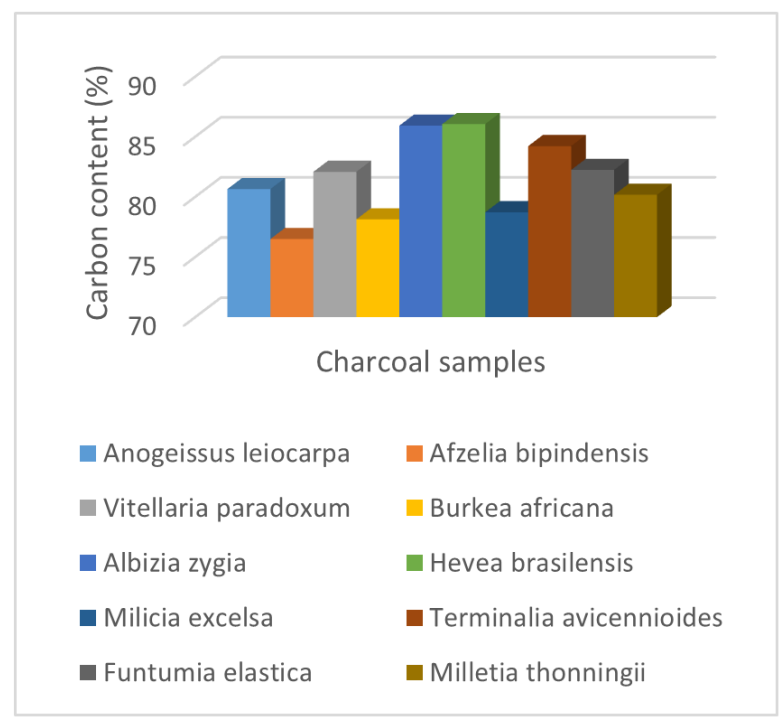

Figure 2. Percentage carbon content for different charcoal species.

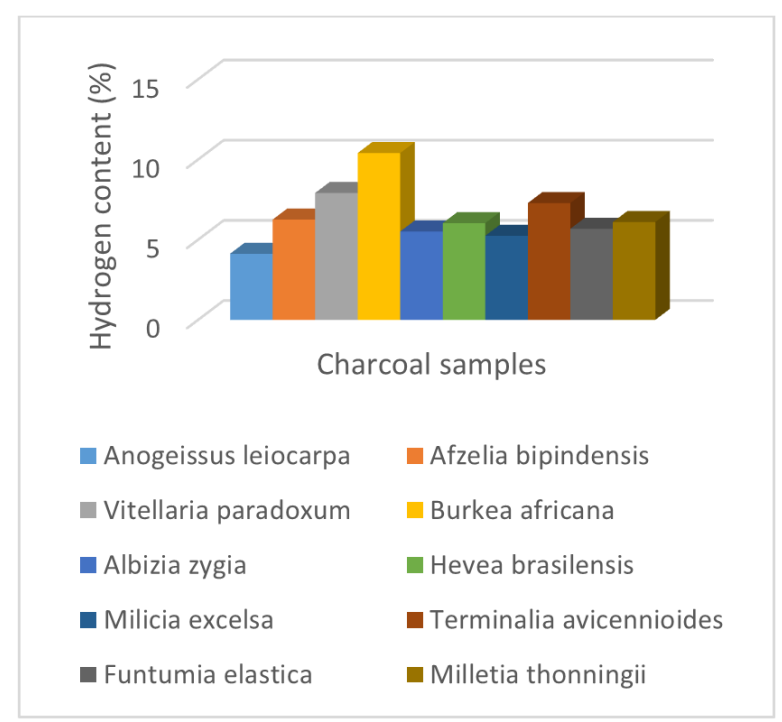

Figure 3. Percentage hydrogen content for different charcoal species.

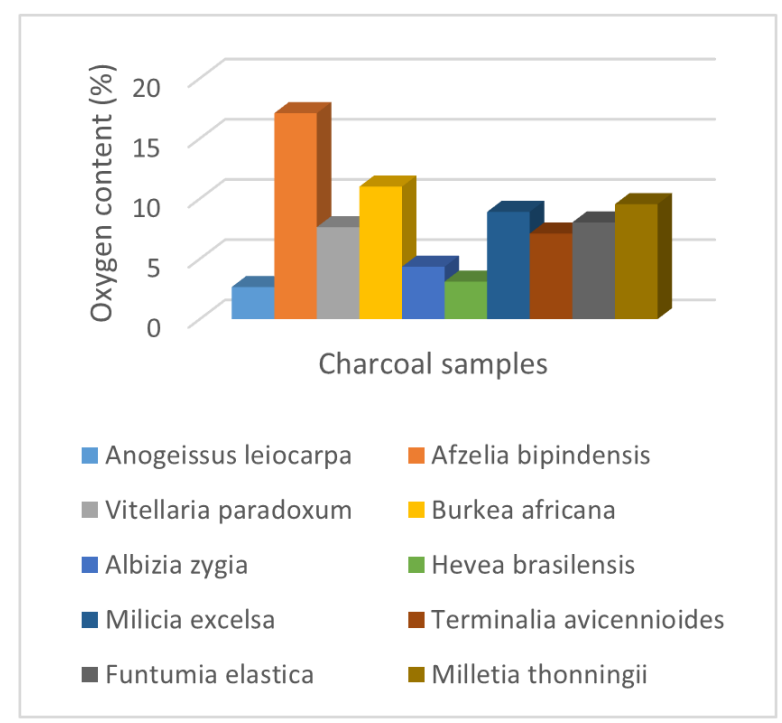

Figure 4. Percentage oxygen content for different charcoal species.

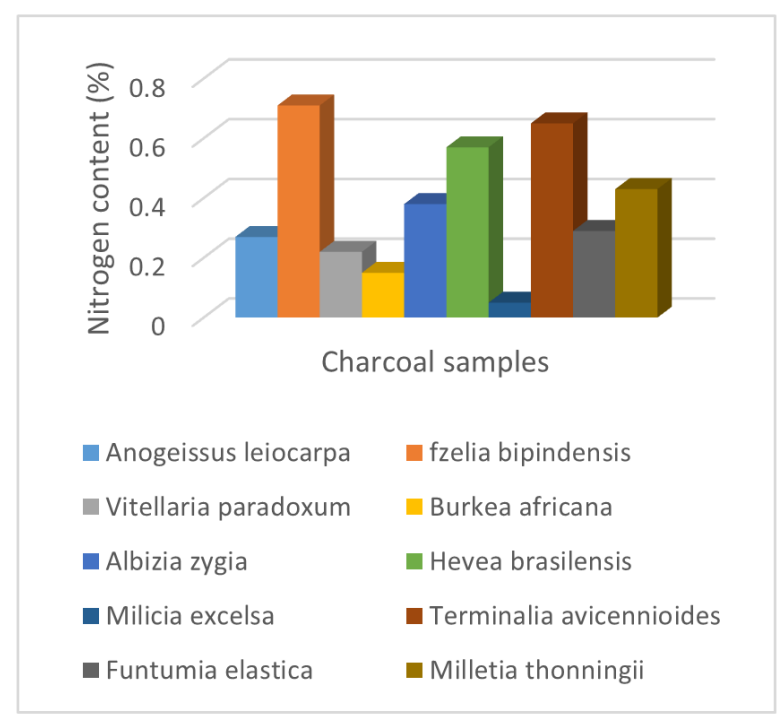

Figure 5. Percentage nitrogen content for different charcoal species.

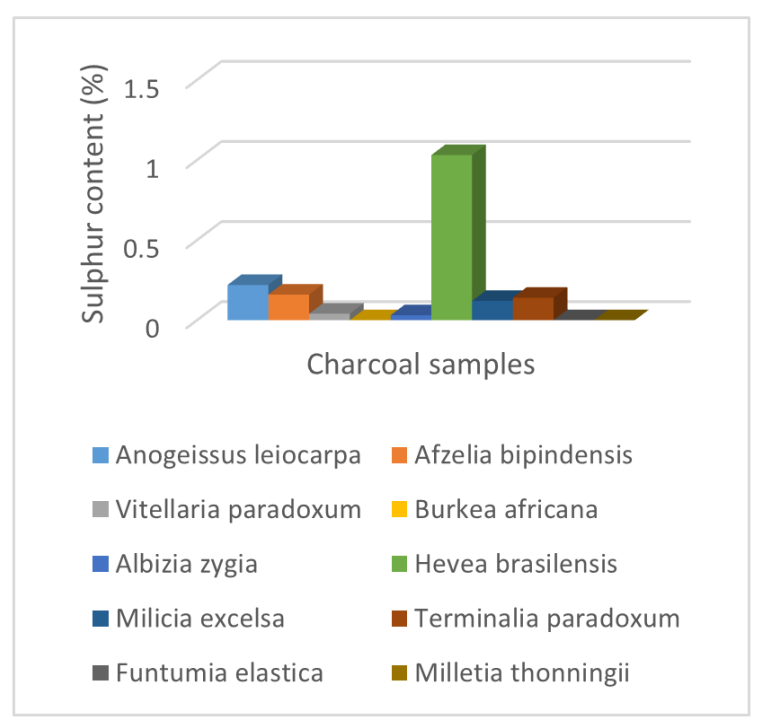

Figure 6. Percentage Sulphur content for different charcoal species.

Silicon exist as silica $\left(\mathrm{SiO}_{2}\right)$ or several silicate minerals. During combustion, usually the several metals associated with silicate remains in the silicate matrix. Combustion in fluidized beds is not affected by Silicates. The ash produced by silicate is usually high melting and majority of the silicate ashes are crystalline in nature under fluidized bed conditions and they don't cause sintering, slagging, fouling, or corrosion problems [26]. During burning, low melting potassium silicate are formed when they react easily with each other and these results in fouling and sintering problem in the fluidized bed. Though their behaviour is rare, the combustion of their silicates and silica may affect the chemistry of other elements that can form ash majorly $\mathrm{Ca}, \mathrm{Na}$, and $\mathrm{K}$ by minor reaction hence causing directly the fouling- corrosion properties of fly ash [26]. The Si percentage between $72 \%$ and $80 \%$ has low slagging propensity. Medium slagging propensity when it is between $65 \%$ and $72 \%$ and high slagging propensity when the $\mathrm{Si}$ percentage is between $50 \%$ and $65 \%$ [27]. Hevea brasilensis (rubber), Milletia thonningii (ito), Funtumia 
elastica (ire), Terminalia avicennioides (idi), Milicia excelsa (iroko), and Albizia zygia (ayunre) have $\mathrm{Si}$ percentage between $50 \%$ and $65 \%$.

Aluminum exists in various forms in charcoal. It form alumina, $\mathrm{Al}_{2} \mathrm{O}_{3}$ in the furnace processes which is a solid (that cannot react) and will not be involved in the chemistry of the ash in the fluidized bed system. In few solid fuels, Aluminum may occur as silicates when the fuel is contaminated with clay or other impurities. Aluminum silicates are less reactive altough they can react with gaseous alkalis, hence affecting the chemistry of the flue ash alkalis. Aluminum metals have the ability to oxidize to alumina $\mathrm{Al}_{2} \mathrm{O}_{3}(\mathrm{~s})$ in combustion processes. They have low melting points. In the furnace or superheaters, it will form agglomerates easily and deposits on tube surfaces (Zevenhoven et al., 2010). Hevea brasilensis (rubber), Milletia thonningii (ito), Funtumia elastica (ire), Terminalia avicennioides (idi), Milicia excelsa (iroko), and Albizia zygia (ayunre) have concentration ranging from $23.08 \mathrm{~g} / \mathrm{kg}$ to 28.12 $\mathrm{g} / \mathrm{kg}$. Rubber and Idi have the highest while Ayunre has the lowest concentration. High values of $\mathrm{Si}$ : Al ratio and increased ash yield are an indication of charcoal formed under unstable conditions as shown in Figure 15. A higher Si: Al ratio that is a value above 2 , shows that the ash fusion temperature changes slightly or remains constant [28]. Hevea brasilensis (rubber), Milletia thonningii (ito), Funtumia elastica (ire), Terminalia avicennioides (idi), Milicia excelsa (iroko), and Albizia zygia (ayunre) have $\mathrm{Si}$ : $\mathrm{Al}$ ratio greater than 4 that is the ash fusion temperature is not serious affected.

Iron exist in different state in solid fuels. During burning, different form of $\mathrm{Fe}$ will produce iron oxides $-\mathrm{Fe}_{2} \mathrm{O}_{3}, \mathrm{FeO}$, and lastly $\mathrm{Fe}_{3} \mathrm{O}_{4}$. It may also be formed under strongly reducing conditions. Compounds of iron can produce first deposits on furnace wall tubes in PF (pulverized fuel) boilers, when temperatures of gas in the furnace are high [29]. Iron is very useful in the body as it helps to transport oxygen to the tissue from the lungs by the red blood cell hemoglobin where it acts as a medium of transportation for electrons within the cells. For many enzymatic reactions, iron serves as one of the major enzyme systems in numerous cells where it serves as a cofactor. It is also present in oxygen storing protein myoglobin where oxygen is stored for working muscles. Funtumia elastica (ire) has the highest concentration of Fe and Vitellaria paradoxum (emi) has the lowest concentration of Fe. The presence of $\mathrm{Fe}$ in charcoal lowers the temperature. Fe content reduces the melting point and viscosity of ash particles [28]. Hevea brasilensis (rubber), Milletia thonningii (ito), Funtumia elastica (ire), Terminalia avicennioides (idi), Milicia excelsa (iroko), and Albizia zygia (ayunre) have low Fe content compare to samples Burkea Africana (asapa), Vitellaria paradoxum (emi), Afzelia bipindensis (ayan), Anogeissus leiocarpa (ayin).

Calcium is found in largest quantity in biomass (woody). Calcium is partly bonded organically and hence can be exchanged in the ammonium acetate leaching. Consequently, in combustion organic calcium in solid fuel is liberated as small solid particles, Calcium oxide [30]. Under hot furnace condition, calcium oxalate (several crystalline forms containing crystal water) in the solid fuel will produce finely divided small oxide particles. Calcium exists in many silicate minerals as part of the solid fuel (peat). In selective leaching tests, calcium is not soluble. Under combustion condition, calcium is also quite inert and usually will not affect the chemistry of the flue gas. During combustion, calcium is used as an additive agent usually in form of $\mathrm{CaCO}_{3}$ to remove Sulphur to absorb free Sulphur dioxide from flue gases. Consequently, for other competing reactions like sulphation of alkalis chlorides, $\mathrm{SO}_{2}$ is not readily available for such reaction [26]. The presence of $\mathrm{Ca}$ and $\mathrm{Mg}$ can be associated with calcite and dolomite minerals. When the weight percentage ratio of $\mathrm{Ca}: \mathrm{Mg}$ is greater than 1, then dolomite is present as shown in Figure 16. Therefore dolomite is present in all except Afzelia bipindensis, (ayan). Usually, calcium dominates over magnesium.

Magnesium induces muscle relaxation. The combustion chemistry of magnesium is less likely when compared with calcium. $\mathrm{Ca}$ and $\mathrm{Mg}$ undergo the same reactions but for $\mathrm{Mg}$, the temperature is very low that it cannot actually have importance in burning processes. In combustion systems, Magnesium oxides are usually considered as rare compound. Magnesium as an essential element represents a moderately mobile $\mathrm{Mg}$ component is biomass [31]. One difference is a corrosion additive of low temperature with magnesium. $\mathrm{MgO}$ can react when the temperature is low, selectively with $\mathrm{SO}_{3}$ and hence leading to decrease in acid due point corrosion. Hevea brasilensis (rubber) $3.20 \mathrm{~g} / \mathrm{kg}$, Milletia thonningii (ito) $2.17 \mathrm{~g} / \mathrm{kg}$, Funtumia elastica (ire) $1.93 \mathrm{~g} / \mathrm{kg}$, Terminalia avicennioides (idi) $1.69 \mathrm{~g} / \mathrm{kg}$, Milicia excelsa (iroko) 1.87 $\mathrm{g} / \mathrm{kg}$, and Albizia zygia (ayunre) $2.53 \mathrm{~g} / \mathrm{kg}$.

During biomass burning, Potassium is the most intriguing element. The higher its concentration, the lower ash melting temperature and therefore results to the production of deposits on the furnace surfaces, corrosion and agglomeration. From the fireside problems point of view, the most interesting ash-forming element is potassium [26]. The challenge of bed sintering, fouling and corrosion is caused by Potassium in biomass fuels. It is important to know the different forms in which potassium exist in the fuel. Here, the selective leaching analysis of the ash-forming matter is very important. Silicate contaminations of the fuel are usually the insoluble part of $\mathrm{K}$. This part of $\mathrm{K}$ is not involved in the major chemistry of the most reactive forms of K. [26]. In solid fuels. Potassium is usually not soluble and occurs as salt in ionic form in the aqueous fluids of the plant or as directly organically bound $\mathrm{K}$ ions. These compounds of $\mathrm{K}$ is efficiently liberated in the burning process and hence mostly present for any further reactions in the flue gases therefore lowering the ash melting temperature. Potassium reacts Sodium dioxide from the flue gases into the fly ash. In this situation where there is high quantity of alkaline earth metals in the fuel this result in a noticeable decrease in the quantity of $\mathrm{SO}_{2}$ in the flue gases. Increase in the concentration of $\mathrm{K}$ results in reduction in the ignition delay time [32]. Hevea brasilensis (rubber) $13.70 \mathrm{~g} / \mathrm{kg}$, Milletia thonningii (ito) $14.44 \mathrm{~g} / \mathrm{kg}$, Funtumia elastica (ire) $13.53 \mathrm{~g} / \mathrm{kg}$, Terminalia 
avicennioides (idi) $16.27 \mathrm{~g} / \mathrm{kg}$, Milicia excelsa (iroko) 17.27 $\mathrm{g} / \mathrm{kg}$, Albizia zygia (ayunre) $15.27 \mathrm{~g} / \mathrm{kg}$, Burkea Africana (asapa) $10.05 \mathrm{~g} / \mathrm{kg}$, Vitellaria paradoxum (emi) $9.80 \mathrm{~g} / \mathrm{kg}$, Afzelia bipindensis (ayan) $9.05 \mathrm{~g} / \mathrm{kg}$, Anogeissus leiocarpa (ayin) $8.80 \mathrm{~g} / \mathrm{kg}$.

Sodium exist in many biomasses though with lower concentration than that of potassium as observed in this study. Moreover, the concentration of sodium is lower in magnitude when compared with potassium. Sodium and potassium have almost the same chemistry. [33] noted that when the concentration of potassium is higher than that of sodium, it leads to a low $\mathrm{Na} / \mathrm{K}$ ratio which is helpful from nutritional point of view as hypertension is associated with high $\mathrm{Na} / \mathrm{K}$ ratio (Figure 17). Increase in ash deposition and fouling boiler is due to lower melting point of sodium and potassium ash thereby forming deposits on the surface of the furnace. High levels of sodium found in many low-rank coals have been found to be responsible for fouling in the combustion chambers [34]. They all have low concentration of sodium which means fouling will be reduced in combustion.

Sulphur is found in biofuel as both as organic sulphur and inorganic sulfate anions. Studies showed that about $75 \%$ sulphur in biomasses (woody) is bound organically and $25 \%$ as soluble alkali sulphates [35]. In plant biomass Sulphur is absorbed through non-organic sulphate forms and transferred through the plant in which sulphate is converted to sulphide and bound with organic molecules to form cysteine (essential amino acid found in proteins [36]. In combustion, only organic Sulphur will be liberated in combustion - mainly as hydrogen sulphide and other reduced gaseous species are then converted (oxidized) to Sulphur dioxide. Sulphur can be associated to the alkali sulphate, it may also be liberated as a result of some decomposition reaction of the alkali sulphate. Majority of the sulphur in biofuels are liberated during burning and will lastly yield Sulphur dioxide which is poisonous to human health at an elevated temperature. Hevea brasilensis (rubber) $15.94 \mathrm{~g} / \mathrm{kg}$, Milletia thonningii (ito) $13.70 \mathrm{~g} / \mathrm{kg}$, Funtumia elastica (ire) $22.35 \mathrm{~g} / \mathrm{kg}$, Terminalia avicennioides (idi) $17.98 \mathrm{~g} / \mathrm{kg}$, Milicia excelsa (iroko) $14.50 \mathrm{~g} / \mathrm{kg}$ and Albizia zygia (ayunre) 15.46 $\mathrm{g} / \mathrm{kg}$.

The concentrations of Titanium are low in all the charcoal samples which show that no impurities are present in the biomass. When concentration of $\mathrm{TiO}_{2}$ is very high, it shows that the biomass is contaminated [31]. This non-essential mostly represents less mobile components in biomass [31]. Because natural biomass does not possess such a high concentration of $\mathrm{Ti}$.

During fossil fuel combustion $\mathrm{Cr}$ is liberated and deposited in lungs. It found in low concentrations; and participates in metabolic processes of saccharides (carbohydrates) and lipids in organism [37]. Universally, the corrosion resistance of a material depends on the concentration of $\mathrm{Cr}$ and $\mathrm{Ni}$. The concentration of $\mathrm{Cr}$ and $\mathrm{Ni}$ is directly proportional to the corrosion resistance. Hevea brasilensis (rubber) $0.79 \mathrm{~g} / \mathrm{kg}$,
Milletia thonningii (ito) $1.02 \mathrm{~g} / \mathrm{kg}$, Funtumia elastica (ire) $0.85 \mathrm{~g} / \mathrm{kg}$, Terminalia avicennioides (idi) $0.90 \mathrm{~g} / \mathrm{kg}$, Milicia excelsa (iroko) $0.74 \mathrm{~g} / \mathrm{kg}$ and Albizia zygia (ayunre) 0.85 $\mathrm{g} / \mathrm{kg}$.

Nickel (Ni) is believed to be an important element [37], but it is also significantly toxic. The most of all the nickel compounds that are released to the air will adsorb to sediment or soil particle therefore becoming immobile. In acidic ground however, nickel will become more mobile. Nickel exist in small amount as essential foodstuff in animals. But nickel is not only beneficial; it can be dangerous when the maximum tolerable amounts are exceeded [38].

However, there is a substantial difference between the concentration required for normal metabolism functioning and the toxic one. Higher $\mathrm{Ni}$ concentrations originate during combustion [24], where the most toxic Nickel compound tetracarbonylnickel $\mathrm{Ni}(\mathrm{CO})_{4}$ which penetrates through body system when inhaled by lungs. From toxicological standpoint, Nickel compound intoxication can cause carcinogenity of respiratory tract and allergic contact dermatitidis. Albizia zygia (ayunre) $8.96 \mathrm{~g} / \mathrm{kg}$, Hevea brasilensis (rubber) $9.59 \mathrm{~g} / \mathrm{kg}$, Milicia excelsa (iroko) 8.57 g/kg. Terminalia avicennioides (idi) 10.53 g/kg, Funtumia elastica (ire) $10.13 \mathrm{~g} / \mathrm{kg}$, Milletia thonningii (ito), $10.14 \mathrm{~g} / \mathrm{kg}$. That is, the charcoals are free from the negative effect of nickel emission.

The origin of cadmium in biomass is deposition in the dissipation of $\mathrm{Cd}$ by human activities, most notably fossil energy use. Cadmium $(\mathrm{Cd})$ is found in biomass in low concentrations where it penetrates from polluted soils due to industrial pollution. Liberating of $\mathrm{Cd}$ occurs also during burning of fossil fuels and Cd can penetrate into soil ([24, 37]). Cadmium adsorbs to organic matter in the soils. It is very dangerous when it is present in the soils as the uptake through food will increase. Acidified soils increase the cadmium uptake by plants. This pose great danger on human and animals depending on such plants for survival. Cadmium can accumulate in the body when such plant are consumed often. Cows may have large amount of cadmium in their kidney through this [38].

Based on their doses, trace metals are harmful and can contaminate meats when they accumulated in the tissues [39]. Renal tube dysfunction have al so been linked to the presence of some levels of cadmium [40]. Albizia zygia (ayunre) $0.35 \mathrm{~g} / \mathrm{kg}$, Hevea brasilensis (rubber) $0.088 \mathrm{~g} / \mathrm{kg}$, Milicia excelsa (iroko) $0.70 \mathrm{~g} / \mathrm{kg}$. Terminalia avicennioides (idi), $0.35 \mathrm{~g} / \mathrm{kg}$, Funtumia elastica (ire) $0.35 \mathrm{~g} / \mathrm{kg}$, Milletia thonningii (ito) $0.44 \mathrm{~g} / \mathrm{kg}$. High loss on ignition suggested that temperature were not high enough and heating is not uniform due to the presence of undecomposed $\mathrm{CaCO}_{3}$. The descriptive statistics for the elemental composition are presented in Table 1. Figures $7-14$ showed the elemental composition of the charcoal samples and figures 7-17 showed the elemental ratio. 


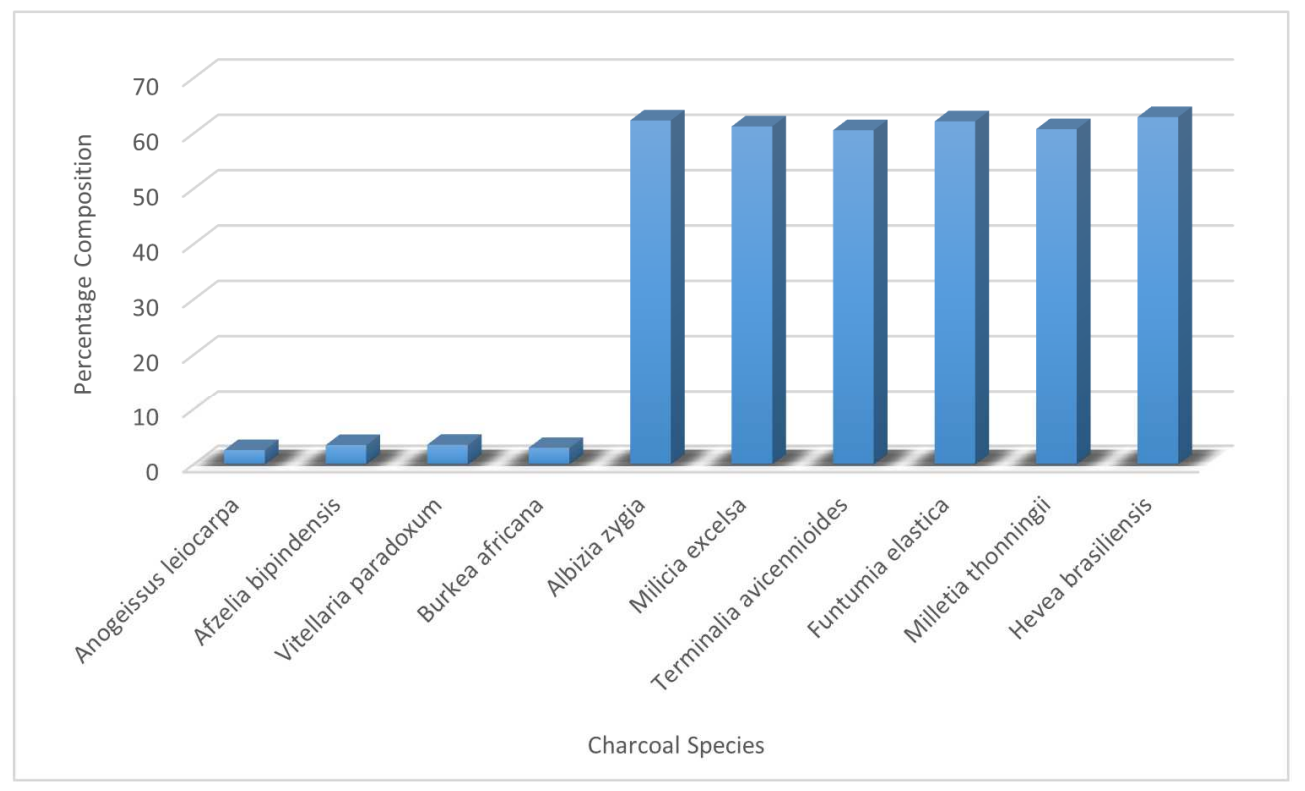

Figure 7. $\mathrm{SiO}_{2}$ content (\%) in the Charcoal Species.

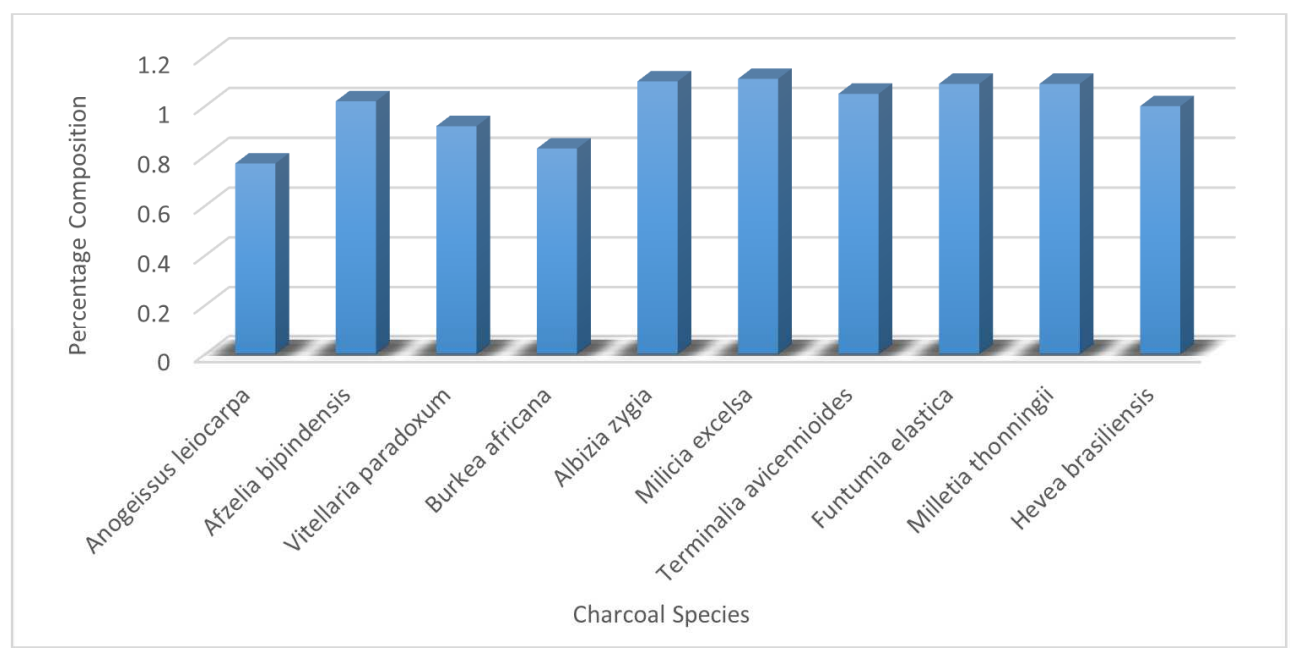

Figure 8. $\mathrm{Al}_{2} \mathrm{O}_{3}$ content (\%) in the Charcoal Species.

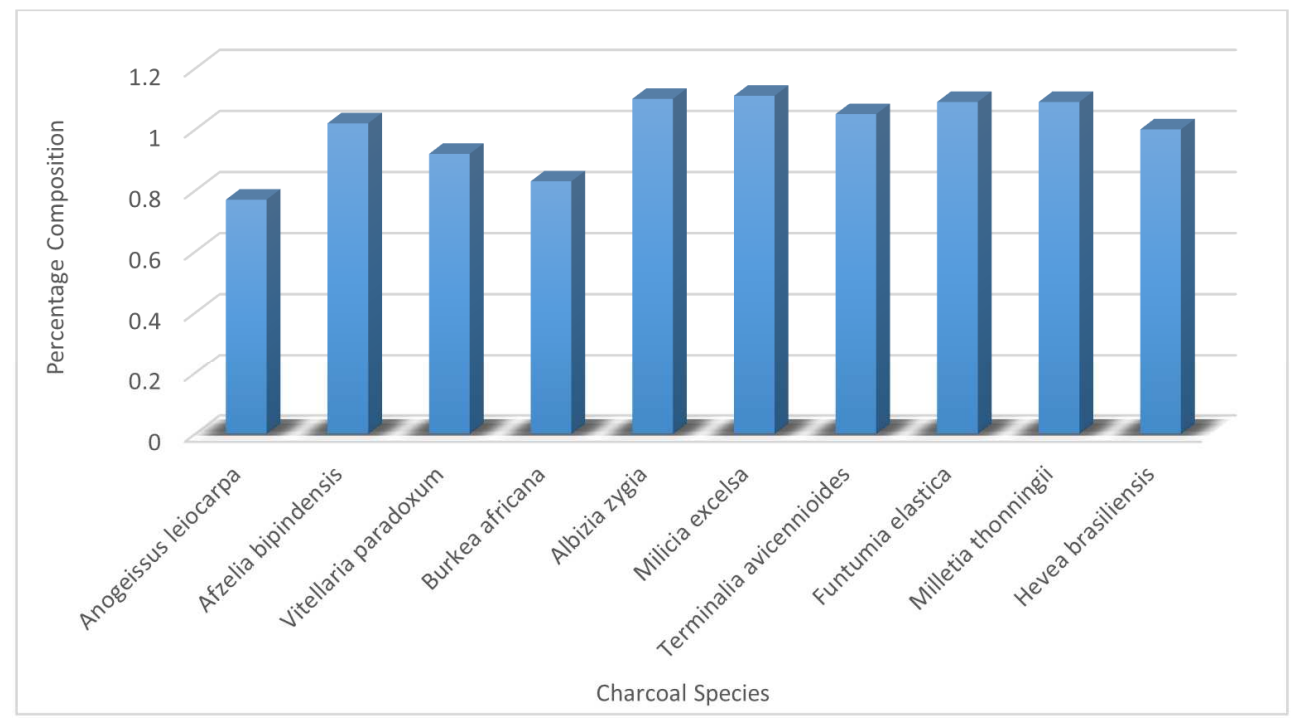

Figure 9. $\mathrm{Fe}_{2} \mathrm{O}_{3}$ content (\%) in Charcoal Species. 


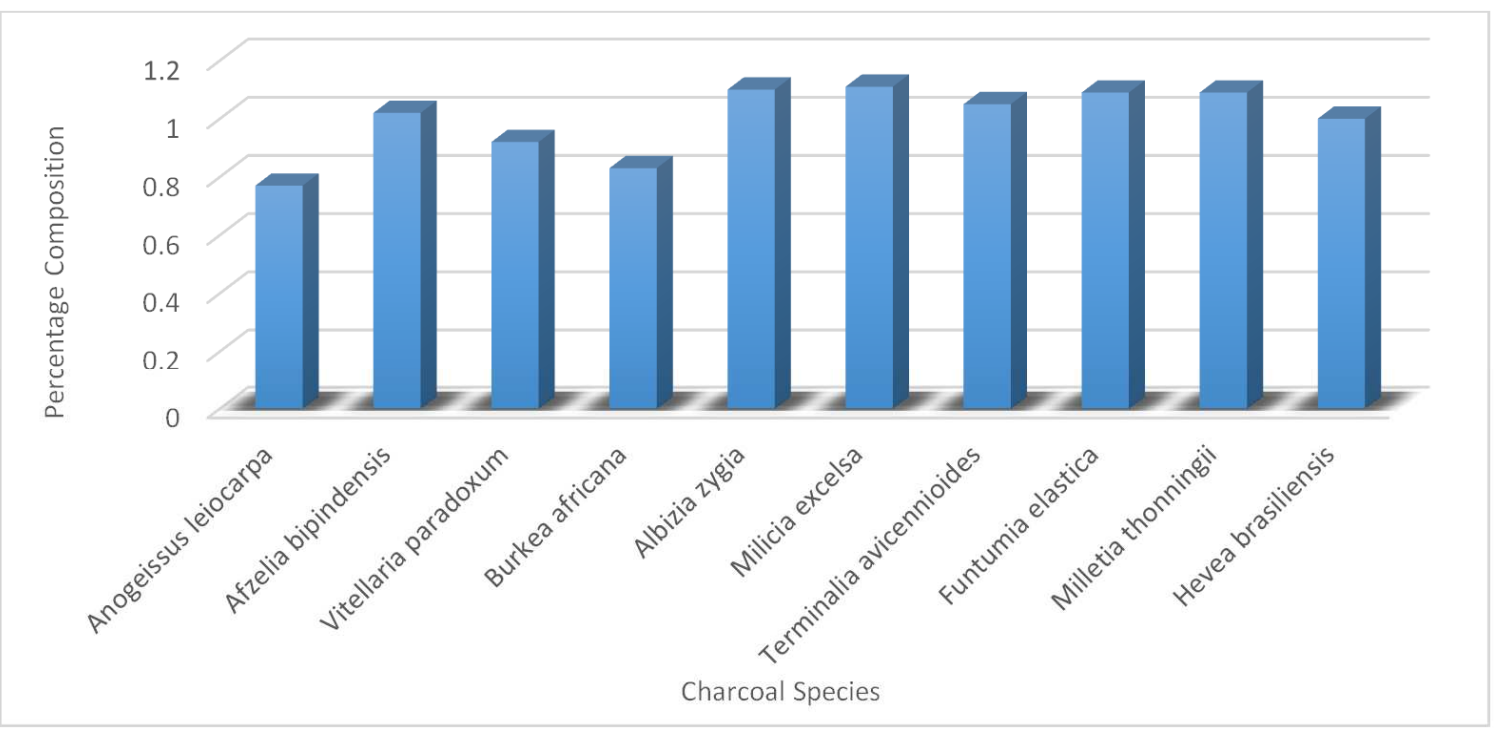

Figure 10. MgO content (\%) in the Charcoal Species.

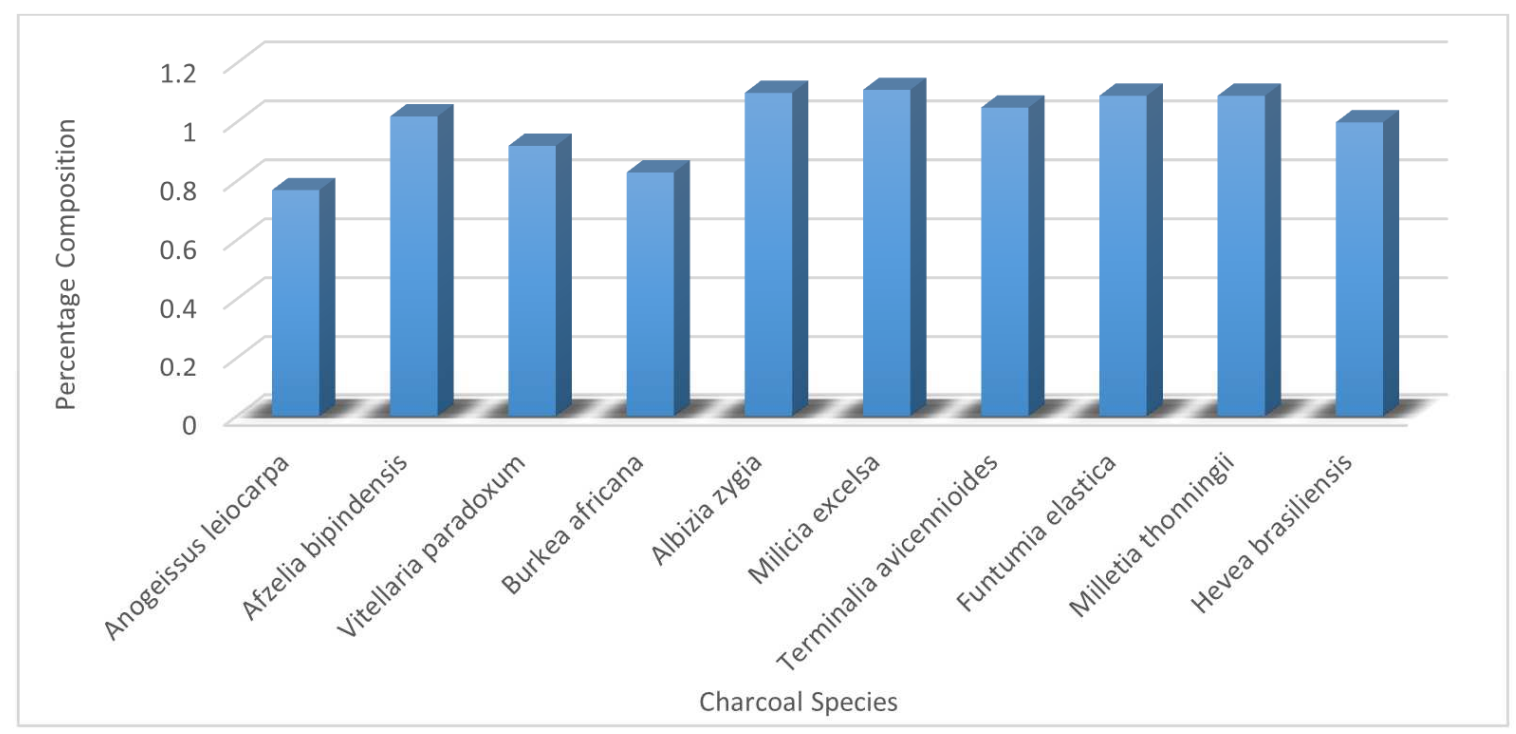

Figure 11. CaO content (\%) in the Charcoal Species.

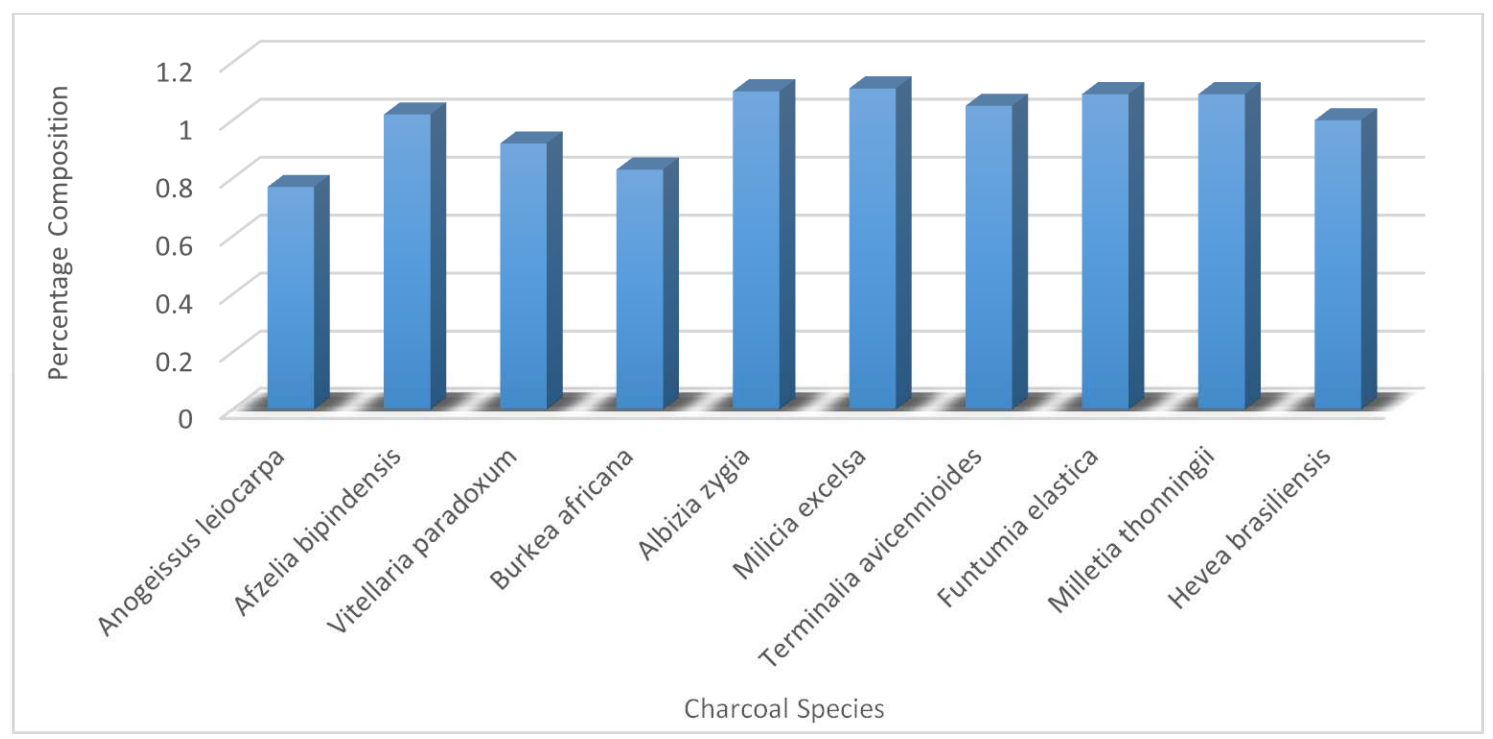

Figure 12. $\mathrm{Na}_{2} \mathrm{O}$ content (\%) in the Charcoal Species. 


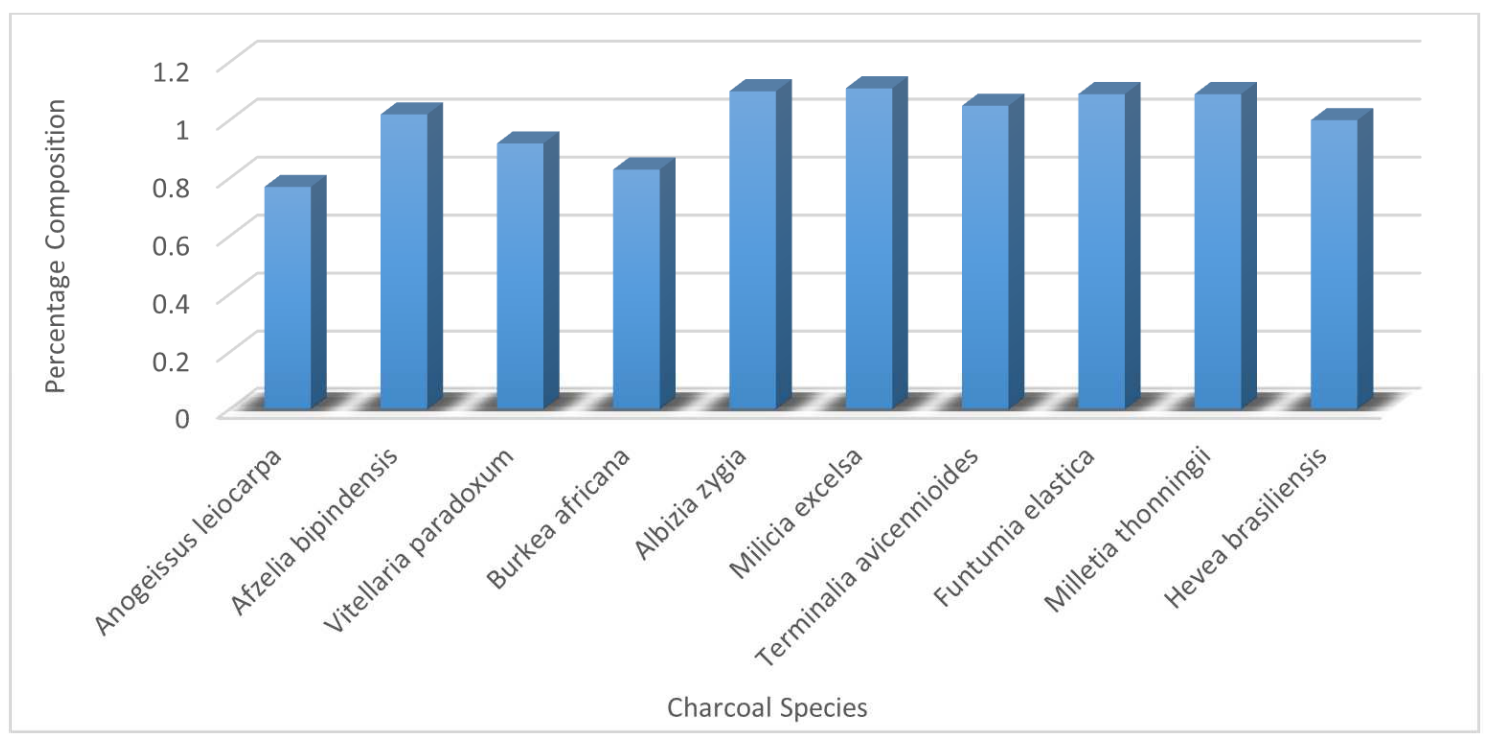

Figure 13. $\mathrm{K}_{2} \mathrm{O}$ content (\%) in the Charcoal Species.

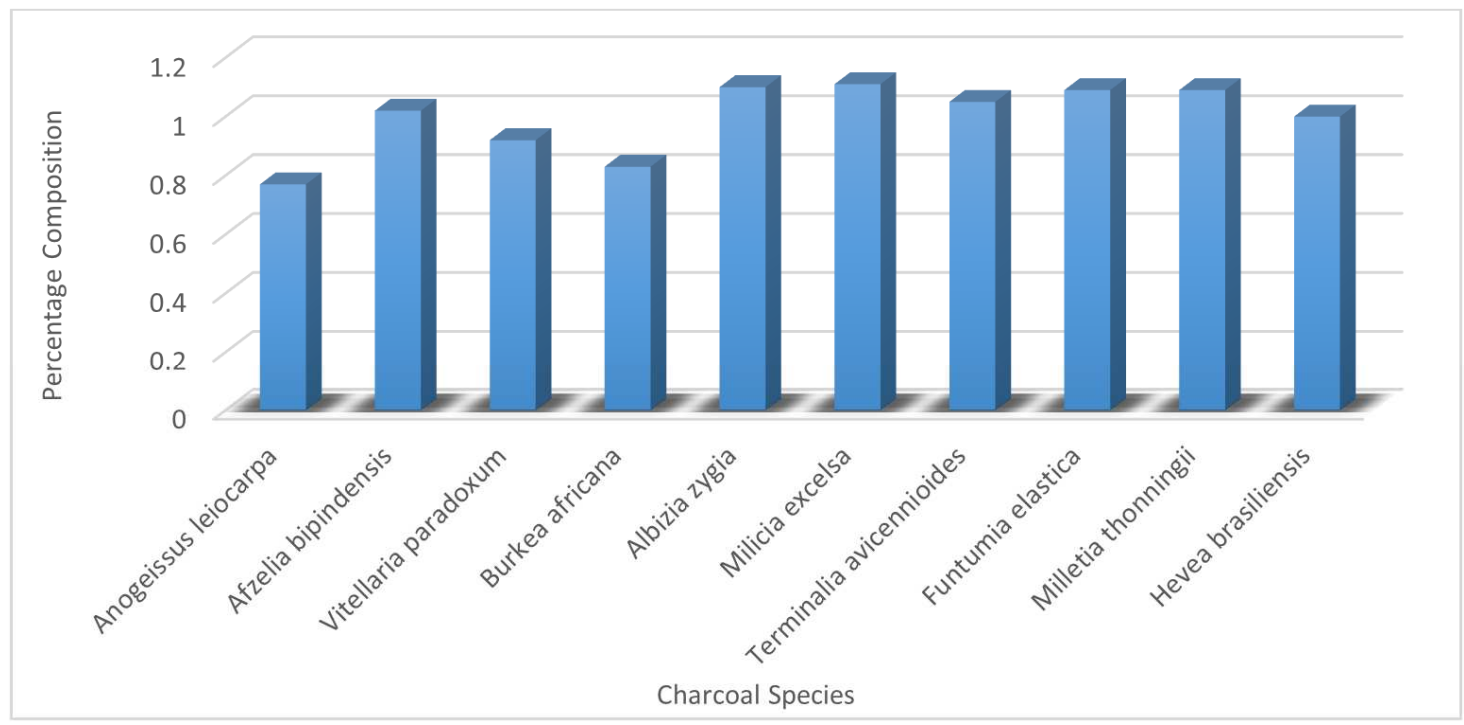

Figure 14. $\mathrm{MnO}$ content (\%) in the Charcoal Species.

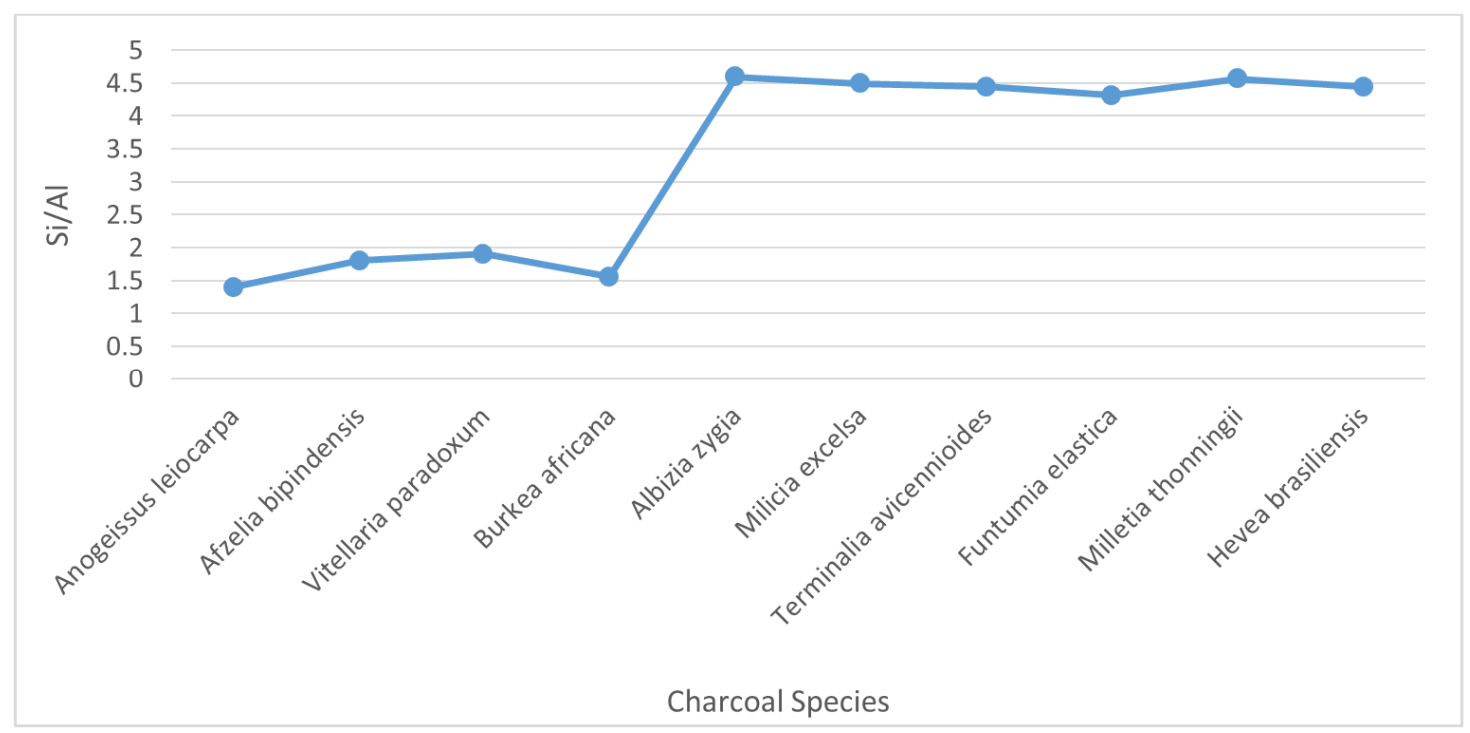

Figure 15. Charcoal Si/Al ratio in the samples. 


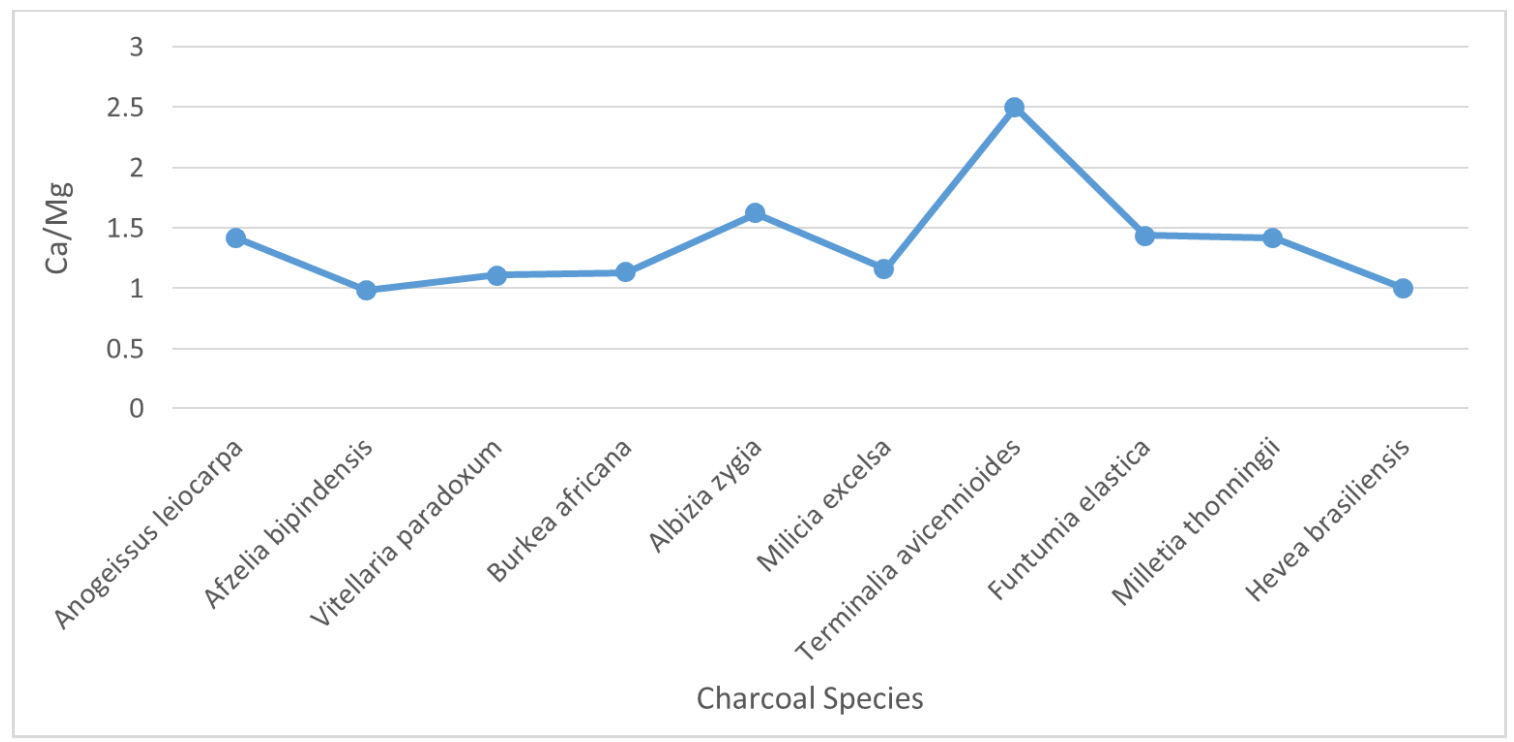

Figure 16. Charcoal Ca/Mg ratio in the samples.

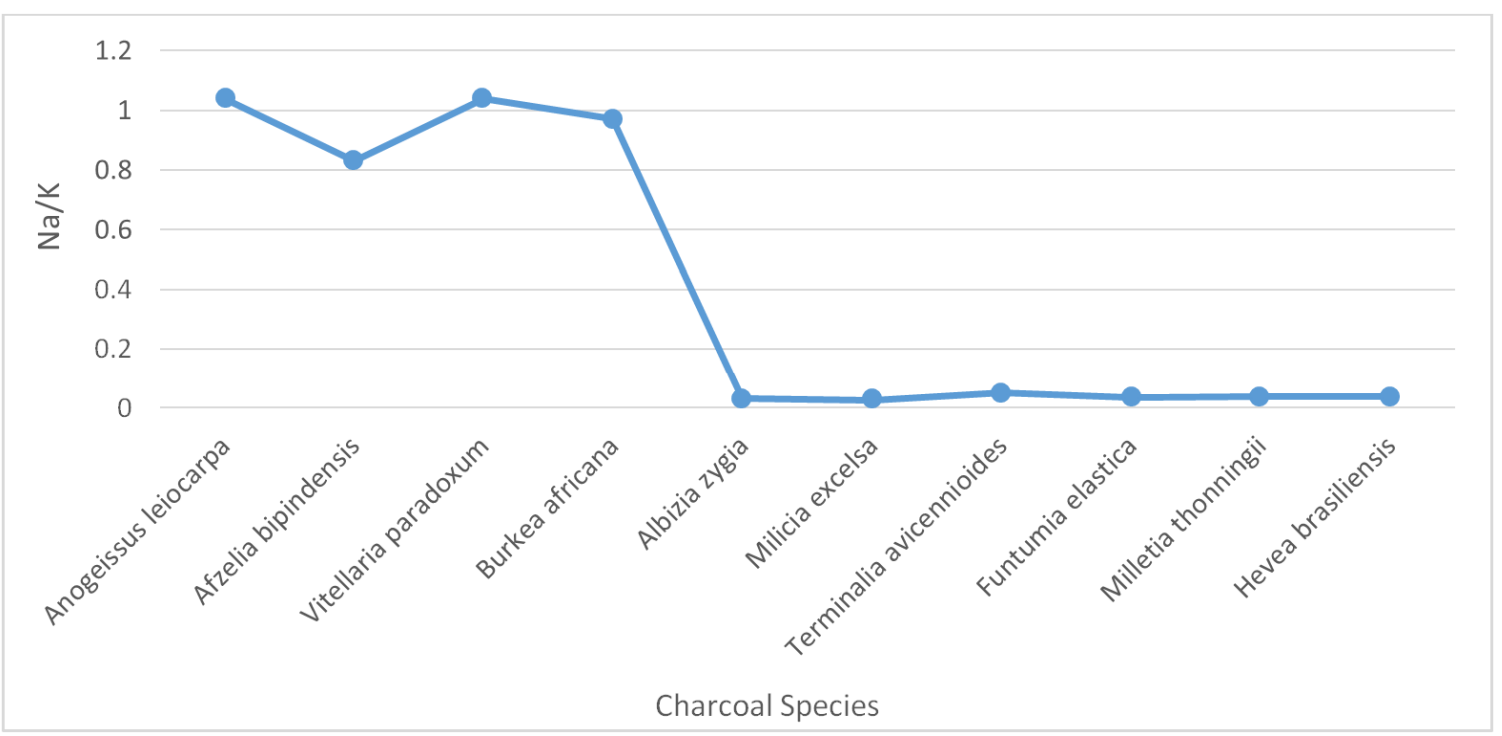

Figure 17. Charcoal Na/K ratio in the samples.

Table 1. Descriptive Statistics of Elemental Composition of the Charcoal.

\begin{tabular}{llllll}
\hline & Mean & Standard Deviation & Maximum & Minimum & Range \\
\hline $\mathrm{SiO}_{2}$ & 179.75 & 142.19 & 294.16 & 11.92 & 282.24 \\
$\mathrm{Al}_{2} \mathrm{O}_{3}$ & 47.73 & 32.58 & 74.25 & 9.63 & 64.62 \\
$\mathrm{Fe}_{2} \mathrm{O}_{3}$ & 97.73 & 94.53 & 213.61 & 23.08 & 190.53 \\
$\mathrm{MgO}$ & 5.14 & 3.83 & 10.43 & 1.69 & 3.74 \\
$\mathrm{CaO}$ & 7.49 & 4.78 & 13.75 & 2.57 & 11.15 \\
$\mathrm{Na}$ & 5.185 & 0.77 & 6.16 & 4.08 & 2.08 \\
$\mathrm{~K}_{2} \mathrm{O}$ & 12.82 & 3.14 & 17.27 & 8.80 & 8.47 \\
$\mathrm{MnO}$ & 7.73 & 0.93 & 8.60 & 5.96 & 2.64 \\
$\mathrm{TiO}_{2}$ & 3.45 & 2.43 & 6.11 & 0.48 & 5.63 \\
$\mathrm{P}_{2} \mathrm{O}_{5}$ & 2.16 & 0.66 & 3.27 & 1.13 & 2.14 \\
$\mathrm{SO}_{3}$ & 16.66 & 3.15 & 22.35 & 13.7 & 8.65 \\
$\mathrm{Cr}_{2} \mathrm{O}_{5}$ & 0.859 & 0.097 & 1.02 & 0.74 & 0.28 \\
$\mathrm{NiO}$ & 9.65 & 0.76 & 10.53 & 8.57 & 1.96 \\
$\mathrm{CdO}$ & 0.38 & 0.20 & 0.70 & 0.088 & 0.61 \\
$\mathrm{LOI}$ & 25.978 & 22.909 & 54.56 & 7.880 & 46.68 \\
\hline
\end{tabular}




\section{Conclusion}

The results of the elemental composition showed that the concentration of sodium, Potassium, magnesium, manganese and titanium in all the charcoal samples are low $1.69-17.27$ $\mathrm{mg} / \mathrm{kg}$. Concentration of chromium, nickel, and cadmium were also low $0.088-10.53 \mathrm{mg} / \mathrm{kg}$, but the accumulation can cause severe damage to human health. Percentage of silicon was between $50 \%$ to $65 \%$ in Albizia zygia, Milicia excelsa, Terminalia avicennioides, Funtumia elastica, Milletia thonningii and Hevea brsiliensis with Hevea brasiliensis having the highest which suggested high slagging propensity. Anogeissus leiocarpa, Afzelia bipindensis, Vitellia paradoxum, and Burkea Africana have high $\mathrm{Na} / \mathrm{K}$ which on accumulation can cause hypertension. The ratio of $\mathrm{Ca} / \mathrm{Mg}$ is greater than 2 in all the samples; this indicates that dolomite is present in all the charcoal samples.

\section{References}

[1] Wang Liang, Øyvind Skreiberg, Sam Van Wesenbeeck, Morten G. Gronli, and Michael Jerry Antal (2016). Experimental Study on Charcoal Production from Woody Biomass. EnergyFuels. 10.1021/acs.energyfuels.6b01039. 1-43.

[2] Ling, Y.-Y., Zhang, J.-J., Liu, K., Ge, M.-H., Wang, M., and Wang, J.-M. (2017). Geochemistry, geochronology, and tectonic setting of Early Cretaceous volcanic rocks in the northern segment of the Tan-Lu Fault region, northeast China. Journal of Asian Earth Sciences, 144, 303-322. doi: 10.1016/j.jseaes.2016.12.025.

[3] Tolosana-Delgado, R., and McKinley, J. (2016). Exploring the joint compositional variability of major components and trace elements in the Tellus soil geochemistry survey (Northern Ireland). Applied Geochemistry, 75, 263-276.

[4] Weltje, G. J., \& Tjallingii, R. (2008). Calibration of XRF core scanners for quantitative geochemical logging of sediment cores: Theory and application. Earth Planet Science Letters, $274(3-4), 423-438$.

[5] Young, K. E., Evans, C. A., Hodges, K. V., Bleacher, J. E., \& Graff, T. G. (2016). A review of the handheld X-ray fluorescence spectrometer as a tool for field geologic investigations on Earth and in planetary surface exploration. Applied'-Geochemistry, 72, 77-87. doi: 10.1016/j.apgeochem.2016.07.003.

[6] Löwemark, L., Jakobsson, M., Mörth, M., \& Backman, J. (2008). Arctic Ocean Mn contents and sediment color cycles. Polar Research, 27, 105-113.

[7] Sabaou, N., Ait-Salem, H., \& Zazoun, R. S. (2009). Chemostratigraphy, tectonic setting, and provenance of the Cambro-Ordovician clastic deposits of the subsurface Algerian Sahara. Journal of African Earth Sciences, 55, 158174.

[8] Rivera, M. B., Giráldez, M. I., \& Fernádez-Caliani, J. C. (2016). Assessing the environmental availability of heavy metals in geochemically contaminated soils of the Sierra de Aracena Natural Park (SW Spain). Is there a health risk?
Science of the Total Environment, 560-561, 254-265.

[9] Oyedotun, T. D. T. (2016). Historical mining signatures: Geochemical and mineralogical evaluation of sediments in three coastal-estuarine systems. Journal of Coastal Zone Management, 19, 432. doi: 10.4172/2473-3350.1000432.

[10] Chalmers, G. R. L., \& Bustin, M. R. (2017). A multidisciplinary approach in determining the maceral (kerogen type) and mineralogical composition of Upper Cretaceous Eagle Ford Formation: Impact on pore development and pore size distribution. International Journal of Coal Geology, 171, 93-110.

[11] Özkul, C., Çiftçi, E., Tokel, S., \& Savaş, M. (2017). Boron as an exploration tool for terrestrial borate deposits: A soil geochemical study in Neogene Emet-Hisarcık basin where the world largest borate deposits occur (Kütahya-western Turkey). Journal of Geochemical Exploration, 173, 31-51.

[12] Fahmi, R.; Bridgwater, A. V.; Donnison, I.; Yates, N.; Jones, J. (2008) The effect of lignin and inorganic species in biomass on pyrolysis oil yields, quality and stability. Fuel, 87, $1230-1240$.

[13] Zhou, L.; Jia, Y.; Nguyen, T.-H.; Adesina, A. A.; Liu, Z. (2013). Hydropyrolysis characteristics and kinetics of potassium-impregnated pine wood. Fuel Process. Technol. $116,149-157$.

[14] Ren, Q.; Zhao, C. (2012). NOx and $\mathrm{N}_{2} \mathrm{O}$ precursors from biomass pyrolysis: Nitrogen transformation from amino acid. Environ. Sci. Technol. 46, 4236-4240.

[15] Raclavska, H.; Corsaro, A.; Juchelkova, D.; Sassmanova, V.; Frantík, J. (2015). Effect of temperature on the enrichment and volatility of 18 elements during pyrolysis of biomass, coal, and tires. Fuel Process. Technol. 131, 330-337.

[16] Bernardo, M.; Goncalves, M.; Lapa, N.; Barbosa, R.; Mendes, , B.; Pinto, F. (2012). Characterization of chars produced in the co-pyrolysis of different wastes: decontamination study. J. Hazard. Mater. 207-208, 28-35.

[17] Keown, D. M.; Favas, G.; Hayashi, J.-i.; Li, C.-Z. (2005). Volatilisation of alkali and alkaline earth metallic species during the pyrolysis of biomass: differences between sugar cane bagasse and cane trash. Bioresour. Technol. 96, $1570-1577$.

[18] Long, J.; Song, H.; Jun, X.; Sheng, S.; Lun-shi, S.; Kai, X.; Yao, Y. (2012). Release characteristics of alkali and alkaline earth metallic species during biomass pyrolysis and steam gasification process. Bioresour. Technol. 116, 278-284.

[19] Agboola S. A. (1979). An Agricultural Atlas of Nigeria, Oxford University Press, Nigeria. P. 248.

[20] NPC (2006). National Population Commission 2006, Abuja, Nigeria.

[21] Faleyimu, O. I., Agbeja, B. O., and Akinyemi, O. (2010). State of forest regeneration in Southwest Nigeria. African Journal of Agricultural Research. 8 (26): 3381-3383.

[22] Borysiuk P., Ružinská, E., Stępowski, A. and Jenczyktołłoczko, I. (2014) Possibility of manufacturing of wooden briquettes with the addition of leaves. In: Annals of Warsaw University of Life Sciences - SGGW. Forestry and Wood Technology. Warsaw. 87: 12-17. 
[23] Boruszewski, P., Maminski, M. and Ružinská, E. (eds.) (2012) Raw materials and particleboards - a current status and perspectives. Monograph. Publish. Warsaw University of Life Sciences - SGGW Press, Warsaw, 111 p. ISBN 978-83-7583389-8.

[24] Ružinská E., Krajewski K. J., Mitterová I., Zachar M. and Toman B. (2014) Assessment of selected hazardous and fire technical characteristics of dendromass intended for wooden pellets preparation. Part I.: Analysis of hazardous substances. Scientific Book: "Advances in Fire, Safety and Security Research 2014”. PTEÚ MV SR, 2014, ročník 1, č. 1. s. 1-10. ISBN 978-80-89051-16-8. ISSN 1339-8490.

[25] Ružinská, E., Wilkowski, J., Mitterová, I. and zachar, M. (2015) The New Progressive Polymeric Materials for the Reduction of VOC in the Woodworking Industry. In: Applied Mechanics and Materials. 711: 214- 217.

[26] Zevenhoven, H., Yrjas, P. and Hupa, M. (2010) Ash -forming Matter and Ash -related Problems. Hand book of Combustion: Solids fuels. 493-531.

[27] Lawrence, A., Kumara, R., Nandakumara, K. and Narayanan. K. 2008. A novel tool for assessing slagging propen-sity of coals in PF boilers. Fuel. 87, 946-950.

[28] Liu, J., Huang, X., Withers, B. R., Blalock, E., Liu, K. and Dickson, R. C. (2013). Reducing sphingolipid synthesis orchestrates global changes to extend yeast lifespan. Aging cell 12 (5): 833-841.

[29] Zevenhoven, M., Lehtovaara, J., Storholm, S., and Hupa, M. (2009) Ash forming matter in peat- the role of iron. Presented at Finnish-Swedish Flame Days, 28-29 January 2009, Naantali, Finland.

[30] Zevenhoven, M. (2001) Ash forming matter in Biomass fuels. Academic Dissertation. Abo Akademi University, Turku Finland. ISBN: 952-12-0813-9.

[31] Vassilev, S. V., Vassileva, C. G., Song, Y-C., Li, W-Y., Feng, J., (2017). Ash contents and Ash forming elements of biomass and their significance for solid biofuel combustion. Fuel. 208: 377-409.
[32] Carvalho, A., Rabaçal, M., Costa, M., Alzueta, M. U., Abián, M. (2017). Effects of potassium and calcium on the early stages of combustion of single biomass particles. Fuel, 209, 787-794.

[33] Choi, M., Scholl, U. I., Yue, P., Bjorklund, P., Zhao, B., Nelson-Williams, C., Ji, W., Cho, Y., Pael, A., and Men, C. J. (2011) $\mathrm{K}+$ channel mutations in adrenal aldosteroneproducing adenomas and hereditary hypertension. Science, $331,768-772$.

[34] Durie, R. (2013) The science of Victorian brown coal: structure, properties and consequences for utilization: Butterworth-Heinemann, $2013 . \quad$ Available: https://www.bookdepository.com/Science-Victorian-BrownCoal-R-Durie/9780750604208.

[35] Werkelin, J. (2008) Ash Forming Matter and their Chemical Forms in Woody Biomass Fuels, PhD thesis, Abo Akademi University.

[36] Liu, W-J., Li, W-W., Jiang, H., and Yu, H-Q (2017) Fates of Chemical Elements in Biomass during its Prolysis. CAS Key. Laboratory of Urban Pollutant Conversion. American Chemical Society. 117: 6367-6398.

[37] Vopršalová, M. and Záčková, P. (2000) Základy toxikologie pro farmaceuty. [Toxicology bases for pharmacists.]. Charles Univerzity, Praha. Publishing house UK Karolinium,. pp. 233 ISBN 80-7184-282-6.

[38] Bhavani, P. and Sujatha, B. (2014) Impact of Toxic metals leading to environmental Pollution. Journal of Chemical and Pharmaceutical Sciences. 70-72.

[39] Beiglbock, C., Steineck, T., Tataruch, F., and Ruf, T. (2001). Environmental cadmium induces histopathological changes in Kidney of roe deer. Environ. Toxicol. Chem.. 12: 1811-1816.

[40] WHO (2003). World Health Survey. Geneva. The World Health Organization. 